\title{
PENGARUH KEJELASAN SASARAN ANGGARAN, BUDAYA ORGANISASI, DAN SISTEM PELAPORAN TERHADAP AKUNTABILITAS KINERJA (STUDI EMPIRIS PADA UNIVERSITAS RIAU)
}

\author{
Susi Heptariani $Z^{1^{*}}$, M. Rasuli ${ }^{2}$, dan Taufeni Taufik ${ }^{2}$ \\ ${ }^{1}$ Program Studi Magister Akuntansi Pasca Sarjana,Universitas Riau \\ ${ }^{2}$ Dosen Fakultas Ekonomi, Universitas Riau \\ E-mail : susi_heptariani@yahoo.com
}

\begin{abstract}
This study aims to examine and analyze how much influence the budget goal clarity, organizational culture and reporting system on performance accountability at the University of Riau. The study was conducted on 54 people at the University of Riau budget users. Respondent participation rate amounted to 90.75\% (49 people). The analytical tool used is multiple regression with SPSS version 21. Tests performed include testing the validity and reliability, testing normality of the data and the classical assumptions, the coefficient of determination and hypothesis testing research. The results showed that the higher budget goal clarity and organizational culture will affect to the higher of performance accountability. Meanwhile, no effect was found between reporting system on performance accountability. The coefficient of determination was $30.2 \%$, where at least $69.8 \%$ change in the performance accountability is influenced by other factors not included in this study.

Keywords: Performance Accountability, Budget Goal Clarity, Organizational Culture, Reporting System
\end{abstract}

\section{PENDAHULUAN}

Universitas Riau saat ini memasuki era persaingan yang semakin ketat, baik di tingkat regional maupun nasional. Berbagai prestasi telah pula diraih, baik dari prestasi mahasiswa, prestasi dosen, prestasi lulusan dan alumni, prestasi di bidang penelitian, maupun kerjasama internasional. Peranan Universitas Riau di dalam kancah regional maupun nasional mulai membanggakan, misalnya dalam pengembangan ilmu dan teknologi, pemberdayaan masyarakat, penyebarluasan hasil penelitian, pengembangan ilmu dan teknologi, serta peranannya di dalam mencetak sumber daya manusia yang handal.

Pada sisi lain, Universitas Riau mempunyai kesejarahan yang kuat karena terikat kepada kebudayaan daerah, khususnya budaya Melayu di Provinsi Riau. Hal ini merupakan modal dasar untuk memperkaya khasanah kebudayaan nasional maupun kebudayaan dunia, khususnya dalam konteks pluralisme dan pencegahan terhomogenisasinya budaya akibat globalisasi. Selain itu, dalam konteks turut mengangkat harkat dan martabat bangsa, sebagaimana yang diamanatkan oleh Pembukaan Undang-Undang Dasar 1945, yaitu mencerdaskan 
derajat kehidupan bangsa melalui pendidikan, khususnya pendidikan tinggi, sebagai bagian dari Sistem Pendidikan Nasional, khususnya pendidikan tinggi, Universitas Riau memiliki peranan yang sangat penting di kawasan ini.

Laporan akuntabilitas kinerja adalah laporan kinerja tahunan yang berisi pertanggung jawaban kinerja suatu instansi dalam mencapai tujuan/sasaran strategis instansi, berupa pengukuran pencapaian target kinerja yang ditetapkan dalam dokumen penetapan kinerja. Sesuai dengan target yang telah direncanakan pada tahun 2012, Universitas Riau berkewajiban untuk dapat mencapai target-target yang telah disepakati bersama dan juga sebagai bentuk pertanggungjawaban kinerja instansi, dan untuk mengetahui tingkat keberhasilan maupun kegagalan organisasi dalam upaya pencapaian sasaran strategisnya dan juga dapat dijadikan bahan evaluasi akuntabilitas kinerja, maka diperlukan suatu gambaran tentang capaian-capaian kinerja tersebut.

Terkait dengan masalah akuntabilitas di Indonesia, menurut Kumorotomo (2010) ada beberapa permasalahan yang berhubungan dengan kinerja akuntabilitas pemerintah daerah. Akuntabilitas itu sendiri merupakan suatu kewajiban untuk menyampaikan pertanggungjawaban untuk menjawab dan menerangkan kinerja dan tindakan seseorang atau badan hukum dan pimpinan kolektif suatu organisasi kepada pihak yang memiliki hak atau berkewenangan untuk meminta keterangan atau pertanggungjawaban (Lembaga Administrasi Negara, 2003). Lingkungan yang mempengaruhi akuntabilitas suatu entitas dapat meliputi lingkungan internal dan eksternal yang dapat membentuk, memperkuat atau memperlemah efektifitas pertanggungjawaban instansi dan tanggungjawab yang dilimpahkan kepadanya (Bastian, 2006).

Perencanaan merupakan bagian yang tidak dapat dipisahkan dari proses manajemen organisasi. Anggaran mengungkapkan apa yang akan dilakukan di masa mendatang. Anggaran dapat diinterpretasikan sebagai paket pernyataan perkiraan penerimaan dan pengeluaran (Bastian, 2006). Kejelasan sasaran anggaran Universitas Riau sangat dibutuhkan dalam upaya peningkatan mutu dan kualitas peranan Universitas Riau sebagai universitas yang terkemuka.

Kebiasaan pada saat ini, tradisi, dan cara-cara umum untuk melaksanakan pekerjaan kebanyakan berasal dari apa yang telah dilaksanakan sebelumnya dan tingkat keberhasilan dari usaha-usaha yang telah dilakukan. Ini membawa kita kepada sumber utama dari budaya sebuah organisasi yaitu para pendirinya. Para pendiri organisasi secara tradisional mempunyai dampak yang penting dalam pembentukan budaya awal organisasi, karena para pendiri tersebut adalah orang-orang yang mempunyai ide awal, mereka juga biasanya mempunyai bias tentang bagaimana ide-ide tersebut harus dipenuhi.

Pelaporan merupakan suatu kegiatan yang dilakukan bawahan untuk menyampaikan hal-hal yang berhubungan yang berhubungan dengan hasil pekerjaan yang telah dilakukan selama satu periode tertentu. Pelaporan 
dilakukan kepada atasan kepada siapa bawahan tersebut bertanggung jawab. Pelaporan adalah aktivitas yang berlawanan arah dari pengawasan, Jika pengawasan dilakukan oleh pihak atasan untuk mengetahui semua hal yang menyangkut pelaksanaan kerja bawahan, maka pelaporan merupakan jawaban dari kegiatan pengawasan tersebut.

Diantara beberapa faktor yang diduga mempengaruhi akuntabilitas kinerja, kejelasan sasaran anggaran, budaya organisasi dan sistem pelaporan menjadi variabel yang hasil penelitian terdahulu masih tidak konsisten. Kejelasan sasaran anggaran dinyatakan berpengaruh terhadap akuntabilitas dalam penelitian terdahulu yang dilakukan oleh Nuraini dan Dewi (2013), Suhartono dan Suyatno (2006), Kusumaningrum (2009), Herawaty (2011), Abdullah (2004),Yahya dkk (2007), Anjarwati (2012), Silvia dan Jayamaha (2012) namun demikian, variabel ini tidak berpengaruh terhadap akuntabilitas dalam penelitian terdahulu yang dilakukan oleh Ardilla (2012). Budaya organisasi terbukti berpengaruh terhadap akuntabilitas dalam penelitian terdahulu yang dilakukan oleh Waring (2011), Silvia dan Jayamaha (2012). Adapun sistem pelaporan terbukti berpengaruh terhadap akuntabilitas dalam penelitian terdahulu yang dilakukan oleh Nuraini dan Dewi (2013), Herawaty (2011), Abdullah (2004), Kusumaningrum (2009), Yahya dkk (2007) dan Anjarwati (2012). Untuk itu perlu dilakukan penelitian kembali tentang pengaruh kejelasan sasaran anggaran, budaya organisasi dan sistem pelaporan terhadap akuntabilitas kinerja.

\section{TINJAUAN PUSTAKA}

\section{Akuntabilitas Kinerja}

Menurut Bastian (2006), akuntabilitas ditujukan untuk mencari jawaban terhadap pernyataan yang berhubungan dengan pelayanan apa, siapa, kepada siapa, milik siapa, yang mana, dan bagaimana. Carino (2008), mengatakan akuntabilitas merupakan suatu evoluasi kegiatan yang dilaksanakan oleh seorang petugas baik masih berada pada jalur otoritasnya atau sudah berada jauh di luar tanggungjawab dan kewenangannya. Dengan demikian, dalam setiap tingkah lakunya seorang pejabat pemerintah mutlak harus selalu memperhatikan lingkungan. Ada 4 (empat) dimensi yang membedakan akuntabilitas dengan yang lain, yaitu siapa yang harus melaksanakan akuntabilitas; kepada siapa dia berakuntabilitas; apa standar yang digunakan untuk penilaian akuntabilitasnya; dan nilai akuntabilitas itu sendiri.

Akuntabilitas kinerja adalah kewajiban untuk memberikan pertanggung jawaban atau menjawab dan menerangkan kinerja dan tindakan seseorang/ badan hukum/ pimpinan suatu organisasi kepada pihak yang memiliki hak atau berkewenangan untuk meminta pertanggung jawaban. Berdasarkan pada 
pengertian yang demikian itu, maka semua Instansi Pemerintah, Badan dan Lembaga Negara di Pusat dan Daerah sesuai dengan tugas pokok masing-masing harus memahami lingkup akuntabilitasnya masing-masing, karena akuntabilitas yang diminta meliputi keberhasilan dan juga kegagalan pelaksanaan misi Instansi yang bersangkutan (LAN RI dan BPKP, 2001: 43).

Laporan akuntabilitas kinerja adalah laporan kinerja tahunan yang berisi pertanggung jawaban kinerja suatu instansi dalam mencapai tujuan/sasaran strategis instansi. Laporan Akuntabilitas Kinerja berisi ikhtisar pencapaian sasaran sebagaimana yang ditetapkan dalam dokumen penetapan kinerja dan dokumen perencanaan. Fokus pelaporan kinerja adalah Permen Nomor 29 Tahun 2010.

\section{Kejelasan Sasaran Anggaran}

Menurut Nordiawan (2009), anggaran adalah sebuah proses yang dilakukan oleh organisasi sektor publik untuk mengalokasikan sumber daya yang dimilikinya ke dalam kebutuhan-kebutuhan yang tidak terbatas (the process of allocating resources to unlimited demands). Pengertian tersebut mengungkap peran strategis anggaran, dalam pengelolaan kekayaan sebuah organisasi publik. Organisasi sektor publik tentunya berkeinginan memberikan pelayanan maksimal kepada masyarakat, tetapi sering kali keinginan tersebut terkendala oleh terbatasnya sumber daya yang dimiliki. Di sinilah fungsi dan peran penting anggaran.

Dalam penyusunan anggaran sektor publik, dapat digunakan pendekatanpendekatan berikut ini:

a. Pendekatan Tradisional (line-item/object of expenditure budget)

b. Pendekatan Kinerja

c. Pendekatan Sistem Perencanaan dan Penganggaran Terpadu (Planning, Programming And Budgeting System - PPBS)

d. Pendekatan Anggaran berbasis Nol (Zero based budgeting)

Pada praktek pelaksanaan sistem anggaran di Universitas Riau, pendekatan yang digunakan hingga saat ini adalah pendekatan kinerja.

Perencanaan merupakan bagian yang tidak dapat dipisahkan dari proses manajemen organisasi. Anggaran mengungkapkan apa yang akan dilakukan di masa mendatang. Anggaran dapat diinterpretasikan sebagai paket pernyataan perkiraan penerimaan dan pengeluaran dimana melalui anggaran dapat dilakukan perencanaan tindakan apa yang akan dilakukan oleh organisasi, berapa biaya yang dibutuhkan, dan berapa hasil yang diperoleh dari belanja pemerintah tersebut (Bastian, 2006). Melalui definisi ini dapat disimpulkan bahwa keberhasilan manajemen organisasi yang diperlihatkan oleh tingginya akuntabilitas kinerja, akan tercapai, salah satunya melalui kejelasan sasaran anggaran. Ketika kejelasan sasaran anggaran tinggi, anggota organisasi dapat 
mengetahui dengan jelas apa yang akan mereka lakukan sehingga pelaksanaan kegiatan akan berjalan dengan lancar dan membuat akuntabilitas kinerja menjadi tinggi.

\section{Budaya Organisasi}

Menurut Nimran (2004) semua organisasi mempunyai budaya yang tidak tertulis yang mendefinisikan standar-standar perilaku yang dapat diterima dengan baik maupun tidak untuk para karyawan. Dan proses akan berjalan beberapa bulan, kemudian setelah itu kebanyakan karyawan akan memahami budaya organisasi mereka seperti, bagaimana berpakaian untuk kerja dan lain sebagainya. Nimran (2004: 372) mendefinisikan budaya organisasi sebagai sistem yang menembus nilai-nilai, keyakinan, dan norma yang ada di setiap organisasi. Kultur organisasi dapat mendorong atau menurunkan efektifitas tergantung dari sifat nilai-nilai, keyakinan dan norma-norma yang dianut.

Lebih lanjut menurut Nimran (2004) semua organisasi mempunyai budaya yang tidak tertulis yang mendefinisikan standar-standar perilaku yang dapat diterima dengan baik maupun tidak untuk para karyawan. Dan proses akan berjalan beberapa bulan, kemudian setelah itu kebanyakan karyawan akan memahami budaya organisasi mereka seperti, bagaimana berpakaian untuk kerja dan lain sebagainya. Ketika budaya organisasi terbentuk dan dijalankan dengan baik, sesuai tujuan organisasi, maka pencapaian kinerja akan menjadi lebih baik dan diwujudkan melalui akuntabilitas kinerja yang baik.

\section{Sistem Pelaporan}

Pelaporan kinerja merupakan refleksi kewajiban untuk merepresentasikan dan melaporkan kinerja semua aktivitas dan sumber daya yang perlu dipertanggung jawabkan. Pelaporan ini merupakan wujud dari proses akuntabilitas. Dalam memenuhi akuntabilitas publik, pemerintah melaporkan kinerja secara detail (Bastian, 2006).

Pelaporan merupakan suatu kegiatan yang dilakukan bawahan untuk menyampaikan hal-hal yang berhubungan yang berhubungan dengan hasil pekerjaan yang telah dilakukan selama satu periode tertentu. Pelaporan dilakukan kepada atasan kepada siapa bawahan tersebut bertanggung jawab. Pelaporan adalah aktivitas yang berlawanan arah dari pengawasan, Jika pengawasan dilakukan oleh pihak atasan untuk mengetahui semua hal yang menyangkut pelaksanaan kerja bawahan, maka pelaporan merupakan jawaban dari kegiatan pengawasan tersebut.

Akuntansi sektor publik memiliki peran penting untuk menyiapkan laporan keuangan sebagai salah satu bentuk pelaksanaan akuntabilitas publik. Akuntansi dan laporan keuangan mengandung pengertian sebagai suatu proses pengumpulan, pengolahan, dan pengkomunikasian informasi yang bermanfaat untuk pembuatan keputusan dan untuk menilai kinerja organisasi. Informasi 
keuangan bukan merupakan tujuan akhir akuntansi sektor publik. Informasi keuangan berfungsi memberikan dasar pertimbangan untuk pengambilan keputusan. Informasi akuntansi merupakan alat untuk melaksanakan akuntabilitas sektor publik secara efektif, bukan tujuan akhir sektor publik itu sendiri. Karena kebutuhan informasi di sektor publik lebih bervariasi, maka informasi tidak terbatas pada informasi keuangan yang dihasilkan dari sistem akuntansi organisasi. Informasi non-moneter seperti ukuran output pelayanan harus juga dipertimbangkan dalam pembuatan keputusan.

\section{Kerangka Pemikiran}

Perencanaan merupakan bagian yang tidak dapat dipisahkan dari proses manajemen organisasi. Anggaran mengungkapkan apa yang akan dilakukan di masa mendatang. Anggaran dapat diinterpretasikan sebagai paket pernyataan perkiraan penerimaan dan pengeluaran dimana melalui anggaran dapat dilakukan perencanaan tindakan apa yang akan dilakukan oleh organisasi, berapa biaya yang dibutuhkan, dan berapa hasil yang diperoleh dari belanja pemerintah tersebut (Bastian, 2006). Melalui definisi ini dapat disimpulkan bahwa keberhasilan manajemen organisasi yang diperlihatkan oleh tingginya akuntabilitas kinerja, akan tercapai, salah satunya melalui kejelasan sasaran anggaran. Ketika kejelasan sasaran anggaran tinggi, anggota organisasi dapat mengetahui dengan jelas apa yang akan mereka lakukan sehingga pelaksanaan kegiatan akan berjalan dengan lancar dan membuat akuntabilitas kinerja menjadi tinggi.

Kejelasan sasaran anggaran dinyatakan berpengaruh terhadap akuntabilitas kinerja dalam penelitian terdahulu yang dilakukan oleh Wulandari (2009), Nuraini dan Dewi (2013) Suhartono dan Suyatno (2006), Herawaty (2011), Abdullah (2004), Kusumaningrum (2009), Yahya dkk (2007), Anjarwati (2012), Silvia dan Jayamaha (2012). Namun demikian, kejelasan sasaran anggaran dinyatakan tidak berpengaruh dalam penelitian terdahlu yang dilakukan oleh Istiyani (2011). Berdasarkan teori dan uraian tersebut maka diajukan hipotesis:

H1: Kejelasan Sasaran Anggaran Berpengaruh Terhadap Akuntabilitas Kinerja.

Menurut Nimran (2004) semua organisasi mempunyai budaya yang tidak tertulis yang mendefinisikan standar-standar perilaku yang dapat diterima dengan baik maupun tidak untuk para karyawan. Dan proses akan berjalan beberapa bulan, kemudian setelah itu kebanyakan karyawan akan memahami budaya organisasi mereka seperti, bagaimana berpakaian untuk kerja dan lain sebagainya. Ketika budaya organisasi terbentuk dan dijalankan dengan baik, sesuai tujuan organisasi, maka pencapaian kinerja akan menjadi lebih baik dan diwujudkan melalui akuntabilitas kinerja yang baik. 
Budaya organisasi terbukti berpengaruh terhadap akuntabilitas dalam penelitian terdahulu yang dilakukan oleh Tjahjono (2006), Waring (2011), Silvia dan Jayamaha (2012). Namun demikian, budaya organisasi dinyatakan tidak berpengaruh dalam penelitian yang dilakukan oleh Kurniawan dan Prastiwi (2010). Berdasarkan teori dan uraian tersebut maka diajukan hipotesis sebagai berikut:

H2: Budaya Organisasi Berpengaruh Terhadap Akuntabilitas Kinerja.

Pelaporan kinerja merupakan refleksi kewajiban untuk merepresentasikan dan melaporkan kinerja semua aktivitas dan sumber daya yang perlu dipertanggungjawabkan. Pelaporan ini merupakan wujud dari proses akuntabilitas. Dalam memenuhi akuntabilitas publik, pemerintah melaporkan kinerja secara detail (Bastian, 2006). Dengan demikian, sistem pelaporan yang berjalan dengan baik akan menghasilkan data-data keuangan yang dilaporkan secara detail dan memperlihatkan akuntabilitas keuangan yang tinggi.

Sistem pelaporan terbukti berpengaruh terhadap akuntabilitas dalam penelitian terdahulu yang dilakukan oleh Mulyana (2010), Nuraini dan Dewi (2013), Herawaty (2011), Kusumaningrum (2009), Yahya dkk (2007), Abdullah (2004) dan Anjarwati (2012). Namun demikian variabel ini tidak berpengaruh terhadap akuntabilitas kinerja dalam penelitian Istiyani (2011) dan Wulandari (2009). Berdasarkan teori dan uraian tersebut maka diajukan hipotesis:

H3: Sistem Pelaporan Berpengaruh Terhadap Akuntabilitas Kinerja.

\section{METODOLOGOI}

Adapun populasi dalam penelitian ini adalah pejabat pengambil keputusan di lingkungan Universitas Riau Pekanbaru sejumlah 168 orang yang terdiri dari pimpinan universitas, pimpinan fakultas dan unit, pejabat struktural dan pejabat perbendaharaan/pengelola keuangan. Adapun jumlah responden yang akan diteliti sebagai sampel adalah 54 orang

\section{Metode Analisis Data}

Metode analisis data menggunakan analisis regresi linear berganda untuk menguji pengaruh kejelasan sasaran anggaran, budaya organisasi, dan sistem pelaporan terhadap akuntabilitas kinerja.

\section{Operasionalisasi Variabel Penelitian}

Variabel dependen dalam penelitian ini adalah adalah akuntabilitas kinerja. Akuntabilitas terkait erat dengan instrumen untuk kegiatan kontrol terutama dalam hal pencapaian hasil pada pelayanan publik dan menyampaikannya secara transparan kepada masyarakat (Arifiyadi, 2008). 
Kuisioner yang digunakan adalah kuisioner dari Suhartono (2006). Indikator yang digunakan adalah:

1. Akuntabilitas Keuangan

2. Akuntabilitas Manfaat

3. Akuntabilitas Prosedural

Variabel independen yang digunakan untuk mengetahui pengaruhnya terhadap akuntabilitas kinerja pada penelitian ini adalah:

Kejelasan Sasaran Anggaran merupakan suatu rencana yang disusun secara sistematis yang meliputi seluruh kegiatan perusahaan, yang dinyatakan dalam unit (kesatuan) moneter dan berlaku untuk jangka waktu (periode) tertentu yang akan datang (Munandar, 2005). Kuisioner yang digunakan adalah kuisioner dari Suhartono (2006). Indikator yang digunakan adalah:

a. Pengumpulan data dan informasi yang diperlukan untuk menyususn anggaran.

b. Pengelolaan dan penganalisaan data dan informasi tersebut untuk mengadakan taksiran-takisiran dalam rangka menyusun anggaran.

c. Menyusun anggaran serta meyajikannya secara teratur dan sistematis.

d. Pengkoordinasian pelaksanaan anggaran.

e. Pengumpulan data dan informasi untuk keperluan pengawasan kerja.

f. Pengolahan dan penganalisaan data tersebut untuk mengadakan interpretasi dan memperoleh kesimpulan-kesimpulan dalam rangka mengadakan penilaian terhadap kerja yang telah dilaksanakan.

Budaya Organisasi Merupakan sistem yang menembus nilai-nilai, keyakinan, dan norma yang ada disetiap organisasi. Kultur organisasi dapat mendorong atau menurunkan efektifitas tergantung dari sifat nilai-nilai, keyakinan dan norma-norma yang dianut Nimran (2004). Kuisioner yang digunakan adalah kuisioner dari Kusumaningrum (2009). Indikator yang digunakan adalah:

a. Budaya mempunyai suatu peran menetapkan tapal batas.

b. Budaya berarti identitas bagi suatu anggota organisasi.

c. Budaya mempermudah timbulnya komitmen.

d. Budaya meningkatkan kemantapan sistem sosial.

Sistem Pelaporan kinerja merupakan refleksi kewajiban untuk merepresentasikan dan melaporkan kinerja semua aktivitas dan sumber daya yang perlu dipertanggungjawabkan. Pelaporan ini merupakan wujud dari proses akuntabilitas. Dalam memenuhi akuntabilitas publik, pemerintah melaporkan kinerja secara detail (Bastian, 2006). Kuisioner yang digunakan untuk mengukur 
sistem pelaporan adalah kuisioner dari Kusumaningrum (2009). Indikator yang digunakan untuk mengukur sistem pelaporan adalah:

a. Penggolongan rekening yang sama antara anggaran dengan realisasinya sehingga dapat dibandingkan dan dihitung penyimpangannya.

b. Pencatatan akuntansi dapat memberikan informasi mengenai realisasi anggaran.

c. Laporan didasarkan pada akuntansi pertanggungjawaban.

\section{HASIL PENELITIAN}

Kuisioner ditujukan kepada 17 pejabat pembuat komitmen, 1 Pejabat Penguji Dan Penandatanganan Surat Perintah Membayar (SPM), 1 Bendahara Penerimaan, 1 Bendahara Pengeluaran, 19 Bendahara Pengeluaran Pembantu, 3 Kepala Biro Universitas, 7 Kabag di lingkungan rektorat, serta 5 Kasubag Keuangan \& Perencanaan Rektorat. Dari kuisioner yang telah kembali diketahui bahwa tidak seluruh kuisioner yang disebar dapat kembali, namun demikian, tingkat pengembalian kuisioner cukup tinggi, yaitu 90,75\%.

Total jawaban responden untuk diperoleh Akuntabilitas Kinerja sebesar 1253 dengan nilai minimal sebesar 294, nilai maksimal 1470, rata-rata 4,26, standar deviasi sebesar 2,152. Total jawaban responden untuk Kejelasan Sasaran Anggaran diperoleh sebesar 1244 dengan nilai minimal sebesar 294, nilai maksimal 1470, rata-rata 4,23, standar deviasi sebesar 2,405. Total jawaban responden untuk Budaya Organisasi sebesar 893 dengan nilai minimal sebesar 196, nilai maksimal 980, rata-rata 4,56, standar deviasi sebesar 1,779. Total jawaban responden untuk sistem pelaporan sebesar 663 dengan nilai minimal sebesar 441, nilai maksimal 735, rata-rata 4,51, standar deviasi sebesar 1,356

Hasil Pengujian Validitas Akuntabilitas Kinerja, Kejelasan Sasaran Anggaran, Budaya Organisasi Dan Sistem Pelaporan memperlihatkan nilai Pearson Correlation yang lebih besar dari o,3, sehingga dapat dinyatakan bahwa seluruh pertanyaan dalam kuisioner yang memuat variabel penelitian telah valid. Adapun hasil pengujian reliabilitas Akuntabilitas Kinerja, Kejelasan Sasaran Anggaran, Budaya Organisasi Dan Sistem Pelaporan memperlihatkan nilai Croanbach Alpha yang lebih besar dari o,6 sehingga dapat dinyatakan bahwa seluruh kuisioner telah reliabel.

\section{Hasil Analisis}

Hasil uji normalitas ditunjukkan dengan normal pp plot yang telah menunjukkan pola distribusi normal, maka model regresi yang diajukan telah memenuhi asumsi normalitas data. Selanjutnya, hasil uji multikolinearitas memperlihatkan bahwa seluruh variabel bebas memiliki nilai VIF yang lebih kecil dari 10 dengan demikian tidak terdapat gejala multikolinearitas dalam penelitian ini. Hasil uji heteroskedastisitas memperlihatkan tidak adanya data yang 
berkelompok, sehingga dapat disimpulkan tidak terjadi heteroskedastisitas dalam model penelitian ini. Dengan memperhatikan nilai Durbin-Watson = 1,877, maka dapat disimpulkan tidak ada gejala autokorelasi.

Persamaan regresi berganda yang terbentuk dari hasil penelitian adalah:

Akuntabilitas Kinerja $=10,183+$ o,288 Kejelasan Sasaran Anggaran + 0,466 Budaya Organisasi - 0,018 Sistem Pelaporan

Persamaan diatas berarti bahwa:

1. Konstanta bernilai 10,183 yang memperlihatkan bahwa jika variabel-variabel bebas dianggap bernilai tetap, maka akuntabilitas kinerja selaku variabel terikat akan bernilai positif sebesar 10,183

2. Kejelasan Sasaran Anggaran bernilai positif o,288 yang memperlihatkan arah hubungan yang positif. Dengan asumsi setiap kenaikan kejelasan sasaran anggaran sebesar 1\% akan menyebabkan kenaikan pada akuntabilitas kinerja sebesar 0,288\%, begitu pula penurunan kejelasan sasaran anggaran sebesar 1\% akan menyebabkan penurunan pada akuntabilitas kinerja sebesar 0,288\%. Dengan asumsi variabel lain dianggap konstan (tetap)

3. Budaya Organisasi bernilai positif o,466 yang memperlihatkan arah hubungan yang positif. Dengan asumsi setiap kenaikan budaya organisasi sebesar $1 \%$ akan menyebabkan kenaikan akuntabilitas kinerja sebesar 0,466\%, begitu pula penurunan budaya organisasi sebesar 1\% akan menyebabkan penurunan pada akuntabilitas kinerja sebesar 0,466\%. Dengan asumsi variabel lain dianggap konstan (tetap)

4. Sistem Pelaporan bernilai negatif o,018 yang memperlihatkan arah hubungan yang negatif. Dengan asumsi setiap kenaikan 1\% sistem pelaporan akan menyebabkan penurunan akuntabilitas kinerja sebesar 0,018, begitu pula penurunan sistem pelaporan sebesar $1 \%$ akan menyebabkan kenaikan akuntabilitas kinerja sebesar 0,018. Dengan asumsi variabel lain dianggap konstan (tetap)

\section{Hasil Pengujian Koefisien Determinasi}

Adjusted $\mathrm{R}^{2}$ adalah 0,302 yang memperlihatkan bahwa variabel bebas yang digunakan dalam penelitian ini mampu menerangkan variabel terikat sebesar 30,2\%. Sementara itu, 69,8\% lainnya perubahan lainnya dijelaskan oleh variabel lain yang tidak digunakan dalam penelitian ini, seperti disiplin fiskal, hubungan institusi, kerangka negosiasi, motivasi, evaluasi anggaran, dll. 


\section{PEMBAHASAN}

\section{Pengaruh Kejelasan Sasaran Anggaran Terhadap Akuntabilitas Kinerja}

Hasil pengujian hipotesis yang pertama adalah $\mathrm{H}_{\mathrm{o}}$ ditolak dan $\mathrm{Ha}_{1}$ diterima karena t-hitung $(2,270)>$ t-tabel $(2,014)$ dan p value $(0,028)<0,05$. Dengan demikian, kejelasan sasaran anggaran berpengaruh terhadap akuntabilitas kinerja. Bentuk pengaruh yang ditimbulkan positif, dimana meningkatnya kejelasan sasaran anggaran akan berpengaruh pada meningkatnya akuntabilitas kinerja.

Anggaran dapat diinterpretasikan sebagai paket pernyataan perkiraan penerimaan dan pengeluaran dimana melalui anggaran dapat dilakukan perencanaan tindakan apa yang akan dilakukan oleh organisasi, berapa biaya yang dibutuhkan, dan berapa hasil yang diperoleh dari belanja pemerintah tersebut (Bastian, 2006). Melalui definisi ini dapat disimpulkan bahwa keberhasilan manajemen organisasi yang diperlihatkan oleh tingginya akuntabilitas kinerja, akan tercapai, salah satunya melalui kejelasan sasaran anggaran. Ketika kejelasan sasaran anggaran tinggi, anggota organisasi dapat mengetahui dengan jelas apa yang akan mereka lakukan sehingga pelaksanaan kegiatan akan berjalan dengan lancar dan membuat akuntabilitas kinerja menjadi tinggi.

Adanya pengaruh kejelasan sasaran anggaran terhadap akuntabilitas kinerja sesuai dengan penelitian Wulandari (2009), Nuraini dan Dewi (2013) Suhartono dan Suyatno (2006), Herawaty (2011), Abdullah (2004), Kusumaningrum (2009), Yahya dkk (2007), Anjarwati (2012) dan Silvia dan Jayamaha (2012) yang menyatakan bahwa kejelasan sasaran anggaran dinyatakan berpengaruh terhadap akuntabilitas kinerja, namun bertentangan dengan penelitian yang dilakukan oleh Istiyani (2011) yang menemukan bahwa tidak ada pengaruh kejelasan sasaran anggaran terhadap akuntabilitas kinerja.

\section{Pengaruh Budaya Organisasi Terhadap Akuntabilitas Kinerja}

Maka hasil untuk pengujian hipotesis yang kedua adalah $\mathrm{H}_{\mathrm{o}}$ ditolak dan $\mathrm{Ha}_{2}$ diterima karena t-hitung $(2,707)>$ t-tabel $(2,014)$ dan p value $(0,010)<0,05$. Dengan demikian, budaya organisasi berpengaruh terhadap akuntabilitas kinerja. Bentuk pengaruh yang ditimbulkan adalah positif, dimana semakin besar budaya organisasi akan berdampak pada semakin besar pula akuntabilitas kinerja.

Menurut Nimran (2004) semua organisasi mempunyai budaya yang tidak tertulis yang mendefinisikan standar-standar perilaku yang dapat diterima dengan baik maupun tidak untuk para karyawan. Ketika budaya organisasi terbentuk dan dijalankan dengan baik, sesuai tujuan organisasi, maka pencapaian kinerja akan menjadi lebih baik dan diwujudkan melalui akuntabilitas kinerja yang baik. Hasil penelitian ini sejalan dengan penelitian 
Tjahjono (2006), Waring (2011) dan Silvia dan Jayamaha (2012) dimana hasil penelitiannya menemukan budaya organisasi berpengaruh terhadap akuntabilitas kinerja, namun bertentangan dengan penelitian yang dilakukan oleh Kurniawan dan Prastiwi (2010) yang tidak menemukan pengaruh antara budaya organisasi dengan akuntabilitas kinerja.

\section{Pengaruh Sistem Pelaporan Terhadap Akuntabilitas Kinerja}

Maka hasil untuk pengujian hipotesis yang ketiga adalah $\mathrm{H}_{\mathrm{o}}$ diterima dan $\mathrm{Ha}_{3}$ ditolak karena t-hitung $(-0,076)<\mathrm{t}$-tabel $(2,014)$ dan p value $(0,940)>0,05$. Dengan demikian, Sistem pelaporan tidak berpengaruh terhadap akuntabilitas kinerja. Besar kecilnya perubahan pada sistem pelaporan tidak berpengaruh pada perubahan akuntabilitas kinerja.

Tidak berpengaruhnya sistem pelaporan terhadap akuntabilitas kinerja memperlihatkan bahwa dalam lingkungan Universitas Riau, tidak masalah sistem pelaporan apa yang digunakan, sejauh hasil akhir dari laporan keuangan tersebut sesuai dengan standar yang telah ditetapkan. Sistem pelaporan jenis apapun pada akhirnya akan dilengkapi dengan data dan informasi perkembangan pelaksanaan program/kegiatan dan data penting lainnya sehingga perbedaan sistem pelaporan tidak akan membuat perubahan pada akuntabilitas kinerja.

Selain itu, sosialisasi sistem pelaporan keuangan di lingkungan Universitas Riau lebih fokus pada Staf di Rektorat, sehingga masing-masing unit pengguna anggaran yang tersebar di masing-masing Fakultas dan lingkungan lainnya di Universitas Riau masih kurang mendapatkan sosialisasi terkait sistem pelaporan keuangan. Hal ini membuat sistem pelaporan anggaran menjadi tidak berpengaruh terhadap akuntabilitas kinerja, karena sebagian besar pengguna anggaran berada di tiap unit, baik Fakultas, Program Pascasarjana, LEMLIT, LPM, dan UPT Perpustakaan Universitas Riau dimana mereka kurang mendapatkan informasi yang dibutuhkan terkait dengan sistem pelaporan.

Hasil penelitian ini bertentangan dengan penelitian Mulyana (2010), Nuraini dan Dewi (2013), Herawaty (2011), Kusumaningrum (2009), Yahya dkk (2007), Abdullah (2004) dan Anjarwati (2012) yang mendapatkan hasil bahwa terdapat pengaruh sistem pelaporan terhadap akuntabilitas kinerja, namun hasil penelitian ini sejalan dengan penelitian Istiyani (2011) dan Wulandari (2009) yang mendapatkan hasil bahwa tidak terdapat pengaruh antara sistem pelaporan dengan akuntabilitas kinerja. 


\section{PENUTUP}

\section{Kesimpulan}

Dari penelitian yang telah dilakukan, diperoleh kesimpulan bahwa kejelasan sasaran anggaran dan budaya organisasi terbukti berpengaruh signifikan terhadap akuntabilitas kinerja, adapun variabel sistem pelaporan tidak berpengaruh terhadap akuntabilitas kinerja. Hal ini dapat disebabkan oleh karena sistem pelaporan jenis apapun pada akhirnya akan dilengkapi dengan data dan informasi perkembangan pelaksanaan program/kegiatan dan data penting lainnya sehingga perbedaan sistem pelaporan tidak akan membuat perubahan pada akuntabilitas kinerja. Selain itu, sosialisasi sistem pelaporan keuangan di lingkungan Universitas Riau lebih fokus pada Staf di Rektorat, sehingga masing-masing unit pengguna anggaran yang tersebar di masingmasing Fakultas dalam lingkungan Universitas Riau masih kurang mendapatkan sosialisasi terkait sistem pelaporan keuangan.

\section{Saran}

Dari penelitian yang telah dilakukan, penulis mencoba memberikan sejumlah saran yang diharapkan dapat berguna dikemudian hari. Diantaranya adalah untuk meningkatkan akuntabilitas kinerja diperlukan adanya peningkatan kejelasan sasaran anggaran dan budaya organisasi yang telah terbukti berpengaruh positif terhadap akuntabilitas kinerja, semakin tinggi kejelasan anggaran dan akuntabilitas kinerja akan berdampak pada semakin tinggi pula akuntabilitas kinerja. Selanjutnya, untuk dapat menimbulkan keseragaman dalam hal sistem pelaporan, Universitas Riau dapat lebih melakukan sosialisasi sistem pelaporan kepada para pengguna anggaran, sehingga munculnya sebuah sistem pelaporan yang sistematis dan seragam diharapkan dapat lebih meningkatkan akuntabilitas kinerja Universitas Riau di masa yang akan datang. Adapun untuk peneliti selanjutnya disarankan menambah variabel penelitian oleh karena koefisien determinasi penelitian ini baru 30,2\%, dimana 69,8\% lagi perubahan pada akuntabilitas kinerja masih dipengaruhi oleh faktor lain yang tidak disertakan dalam penelitian ini seperti disiplin fiskal, hubungan institusi, kerangka negosiasi, motivasi, evaluasi anggaran, dan lain-lain.

\section{DAFTAR PUSTAKA}

Abdullah, Hilmi. 2004. Pengaruh Kejelasan Anggaran, Pengendalian Akuntansi, dan Sistem Pelaporan Terhadap Kinerja Instansi Pemerintahan pada Kabupaten dan Kota di Daerah Istimewa Yogyakarta. Tesis. Yogyakarta. Universitas Gajah Mada.

Adisaputro, Gunawan dan Marwan Asri. 2009. Anggaran Perusahaan. Edisi ke tiga. Yogyakarta. BPFE.

Arifiyadi, Teguh. 2008. Konsep tentang akuntabilitas dan implementasinya di Indonesia. Jakarta. Universitas Indonesia. 
Anjarwati, Mei. 2012. Pengaruh Kejelasan Sasaran Anggaran, Pengendalian Akuntansi Dan Sistem Pelaporan Terhadap Akuntabilitas Kinerja Instansi Pemerintah. Semarang. Accounting Analysis Journal Vol. 1 No. 2, ISSN 2252-6765, Hal 1-36. Universitas Negeri Semarang.

Bastian, Indra. 2006. Akuntansi Sektor Publik. Jakarta. Airlangga.

Carino, Ledvina V. 2008. Ekonomi Pembangunan dan Perencanaan. Jakarta. Rajawali Pers.

Casio, Waynw F, 2003. Managing Human Resource: Productivity, Quality of Work Life, Profit. Singapore. McGraw-HillInternational Editors.

Deliarnov. 2006. Ekonomi Politik. Jakarta. Erlangga.

Ghozali, Imam. 2005. Analisis Statistik Univariat dengan SPSS. Yogyakarta. BPFE-UGM.

Gujarati, Damodar. 2005. Essential of Econometrics. New York. McGraw-Hill.

Hafidhuddin, Didin., Henry Tanjung., Fachruddin. 2003. Perekonomian Modern. Jakarta: Gema Insani.

Hartono. 2009. Statistik Untuk Penelitian. Yogyakarta: Pustaka Pelajar.

Herawaty, Netty. 2011. Pengaruh Kejelasan Sasaran Anggaran, Pengendalian Akuntansi, dan Sistem Pelaporan Terhadap Akuntabilitas Kinerja Instansi Pemerintah Daerah Kota Jambi. Jurnal Penelitian Universitas Jambi Seri Humaniora. Volume 13, Nomor 2, Hal. 31-36. ISSN o8528349. Jambi. Universitas Jambi.

Hery. 2009. Teori Akuntansi. Jakarta. Kencana Prenada Media Group.

Istiyani. 2011. Pengaruh Karakteristik Anggaran Terhadap Akuntabilitas Kinerja Pemerintah Daerah (Studi Empiris Pada Pemerintah Kabupaten Temanggung) Jurnal Akuntansi Dan Bisnis Vol 7 No 1. Universitas Surakarta.

Kane. 2003. Investments. Jakarta: Salemba Empat.

Kumorotomo, Wahyudi. 2010. Akuntabilitas Birokrasi Publik. Sketsa pada Masa. Transisi. Yogyakarta: Pustaka Pelajar.

Kurniawan, Muhammad Rizki Nur., Andri Prastiwi. 2010. Pengaruh Komitmen Organisasi, Budaya Organisasi Dan Kepuasan Kerja Terhadap Akuntabilitas Kinerja Organisasi Publik. Jurnal Dinamika Pembangunan Vol. 2 No. 2. Universitas Diponegoro.

Kusumaningrum, Indrawati. 2009. Pengaruh Kejelasan Sasaran Anggaran, Pengendalian Akuntansi Dan Sistem Pelaporan Terhadap Akuntabilitas Kinerja Instansi Pemerintah Provinsi Jawa Tengah. Tesis. Semarang. Universitas Diponegoro.

Mulyadi. 2003. Sistem Akuntansi. Jakarta. Cetakan Keempat Salemba Empat.

Munandar. 2005. Budgeting, Perencanaan Kerja Pengkoodinasian Kerja. Pengawasan Kerja. Edisi Pertama. Yogyakarta: BPFE-UGM.

Machfoedz, Mas'ud. 2008. Kewirausahaan. Metode, Manajemen dan Implementasi. Yogyakarta. BPFE-UGM.

Mohyi, Ach. 2004. Teori \& Prilaku Organisasi. UMM Press Malang.

Mulyana, Budi. 2006. Pengaruh Penyajian Neraca Daerah dan Aksesibilitas Laporan Keuangan terhadap Transparansi dan Akuntabilitas Pengelolaan Keuangan Daerah. Jurnal Akuntansi Pemerintahan Vol. 2, No. 1. 
Ndraha, Taliziduhu. 2007. Metodologi Ilmu Pemerintahan. PT Rineka Cipta: Jakarta.

Nordiawan, Deddi. 2009. Akuntansi Sektor Publik. Salemba Empat. Jakarta.

Nimran. 2004. Perilaku Organisasi. Jakarta. PT. Pustaka Binaman Pressindo.

Nuraini,. Dian Indu Dewi. 2013. Pengaruh Kejelasan Sasaran Anggaran, Pengendalian Akuntansi, Dan Sistem Pelaporan Terhadap Akuntabilitas Kinerja Instansi Pemerintah Kabupaten Brebes. Solusi ISSN 1412-5331, Vol 1 No. 4, Hal. 63-77. Universitas Semarang.

Riduwan, 2009. Metode \& Teknik Menyusun Proposal Penelitian. Alfabeta. Bandung.

Saleh, Sirajudin H dan Aslam Iqbal. 2008. Accountability The Endless Prophecy. Asian and Pacific Develompent Centre.

Santoso, Singgih. 2005. Mengatasi Berbagai Masalah Statistik. Jakarta : Elex Media Komputindo

Sevilla, Joaquin. 2005. Accountability and Control of Public Spending in a Decentralised and Delegated Environment. OECD Journal On Budgeting Vol. 5 No. 2. ISSN 1608-7143. Hal. 7-2O. New Cork. Prantice Hall.

Silva, L.M.D dan Jayahama E. 2012. Budgetary Process and Organization Performance of Apparel Industry in Srilanka. Srilanka. Journal of Emerging Trends in Economics and Management Sciences (JETEMS). ISSN: 2141-7024. Hal. 354-36o. University of Kelayina.

Suhartono, Ehrmann dan Suryanto. 2006. Pengaruh Kejelasan Sasaran Anggaran Terhadap Akuntabilitas Kinerja Instansi Pemerintah Daerah Dengan Komitmen Organisasi Dan Motivasi Sebagai Pemoderasi. Jurnal Ekono Insentif Kopwil 4, Vol. 1, No. 1. ISSN: 1907-0640, Hal. 42-35. Universitas Teknologi Yogyakarta.

Supriyono, Andi. 2006. Pemeriksaan Akuntansi (Auditing). Yogyakarta. Salemba Empat.

Tjahjono, Binawan Nur. 2006. Pengaruh motivasi kerja dan budaya organisasi terhadap akuntabilitas kinerja di lingkungan Dinas Marga Propinsi Jawa Tengah. Tesis. Universitas Muhadiyah Surakarta.

Waring, Sara. 2011. An Examination of The Impact of Accountability and Blame Culture on Police Judgements and Decisions in Critical Incident. Disertasi. Liverpool. University of Liverpool.

Widarjono, Agus. 2005. Akuntansi Sektor Publik Di Indonesia. BPFE Yogyakarta.

Wulandari, Ratna Putri. 2009. Pengaruh Kejelasan Sasaran Anggaran, Pengendalian Akuntansi Dan Sistem Pelaporan Terhadap Persepsi Aparatur Pemerintah Daerah Atas Akuntanbilitas Kinerja Instansi Pemerintah. Jurnal Vo. 5 No. 5 . UNNES. Semarang

Yahya, Muhammad Nur., Maya Febrianty Lautania., Senni Juniawati Bunga, 2007. Pengaruh Kejelasan Sasaran Anggaran, Pengendalian Akuntansi Dan Sistem Pelaporan Terhadap Akuntabilitas Kinerja Instansi Pemerintah Daerah Kota Banda Aceh. Pusat Dokumentasi Dan Informasi Ilmiah- Lembaga Ilmu Pengetahuan Indonesia. Jakarta.

UU No. 17 tahun 2003. Tentang Keuangan Negara. Jakarta.

UU No.32 tahun 2004. Tentang Pemerintahan Daerah. Jakarta.

Inpres No. 7 tahun 1999. Akuntabilitas Kinerja Instansi Pemerintah. Jakarta. 
Pengaruh Kejelasan Sasaran, Budaya Organisasi, dan Pelaporan Terhadap Akuntabilitas Kinerja Susi Heptariani Z, M. Rasuli, dan Taufeni Taufik

LAN. 2003. Pedoman Penyusunan Akuntabilitas Kinerja Instansi Pemerintah. Jakarta.

Peraturan Menteri Negara Pendayagunaan Aparatur Negara Dan Reformasi Birokrasi Nomor 29 Tahun 2010. Tentang Pedoman Penyusunan Penetapan Kinerja Dan Pelaporan Akuntabilitas Kinerja Instansi Pemerintah. Jakarta. 